International Journal of Advanced Academic Research (Sciences, Technology and Engineering) | ISSN: 2488-9849

Journal DOI: 10.46654/ij.24889849

Vol. 6, Issue 10 (October, 2020) |www.ijaar.org

Article DOI: 10.46654/ij.24889849.e61016

\title{
ANALYSIS OF POULTRY EGG MARKETING IN IJEBU-ODE LOCAL GOVERNMENT AREA, OGUN STATE, NIGERIA
}

\author{
${ }^{1}$ Jatto K.A., ${ }^{2}$ Adeoye A.S., ${ }^{2}$ Oke O.O., ${ }^{1}$ Ogunbela A.A. and ${ }^{1}$ Lawal M.O.
}

${ }^{1}$ Department of Forest Economics and Extension,

Forestry Research Institute of Nigeria, P.M.B 5040, Jericho, Ibadan, Nigeria.

${ }^{2}$ Department of Agricultural Extension and Management, Federal College of Forestry, P.M.B. 5087, Jericho, Ibadan, Nigeria.

"Corresponding author: samalaba77@gmail.com; +2348037657876

\begin{abstract}
The study analyzed the marketing of poultry eggs in Ijebu-Ode Local Government Area of Ogun State, Nigeria. The objectives of the study were to examine the socio-economic characteristics of poultry egg marketers, determine the profitability of poultry egg market, examine the marketing efficiency, examine the factors that influence the sales revenue, and examine the problems associated with poultry egg marketing in the study area. Purposive sampling procedure was used in selecting the study area while simple random sampling technique was used in selecting a total number of eighty-one respondents. Data was collected with a well-structured questionnaire. The data were analyzed using descriptive statistics, gross margin, and Ordinary Least Square (OLS) regression model. The result showed that the majority of the respondents were female (66.7\%) with most of them in their active age (60.5\%), they were fairly educated (60.5\%) and married (54.3\%). The results of the study revealed that poultry egg marketing is a profitable business. The result also revealed that the cost of purchase of the sellers per day in Ijebu-ode accounted for $76.2 \%$ of the total cost while labour cost and transportation cost are $8.89 \%$ and $8.57 \%$ respectively. The total variable cost was $11,078,707.00$. New market was more efficient than Oke-Aje market. The cost of purchase and transportation cost are the significant factors that contribute to the sales revenue $(p<0.01)$ of egg marketers. The major associated problems with egg marketing in Ijebu-Ode were poor pricing, poor transportation facilities, loss due to breakages and inadequate storage facilities. Introduction of effective pricing mechanism and advocacy on provision of good and accessible roads to minimize loss through the nexus of Poultry Association of Nigeria and the marketers were recommended.
\end{abstract}

Keywords: Poultry eggs, Gross margin, Marketing efficiency, Ijebu-Ode 


\section{INTRODUCTION}

Poultry is the term used for a collection of birds that are reared or hunted for a useful purpose by man. According to Oji and Chukwuma (2007), the poultry goes a long way in providing animal protein for the populace, because it yields quick returns and provides meat and eggs in a very short time. The egg as a major product of poultry is one of the most nutritious and complete food known to man. Being the cheapest per unit source of animal protein, eggs are more readily affordable by the populace than other sources of animal protein (Abanikannda et al., 2007).

In Nigeria, the demand for poultry egg has risen from 500,000 metric tonnes in 1980 to about 1,500000 metric tonnes in 2012 (FAO, 2012). Poultry eggs have assumed the role of providing much needed animal protein to mankind (Aihonsu and Sunmola, 1999). According to Alabi and Isah (2002), poultry eggs contributed to the palatability of many dishes by adding about the same amount of animal protein as pork and poultry meat. Poultry egg has attained industrial importance as a major ingredient in the baking of confectioneries. Also egg albumen is used in the making of shampoo, as well as book binding (Rahman and Yakubu, 2005). The need for animal protein in human diet has been recognized for long. In recent times, consumptions of most Nigerians have declined to an unbearable level. Malnutrition in human diet has been a major issue being debated on worldwide. Mostly in the developing countries, cases of poor health condition were traced to lack or inadequate animal protein in their diet.

Poultry eggs play a very useful role in bridging the protein gap in Nigeria. They are palatable and generally acceptable. This acceptability cuts across nearly all cultural and religious boundaries in the country. The importance of poultry to the national economy cannot be overemphasized, as it has become popular industry for the smallholders that have great contribution to the economy of the country. The enterprise has assumed greater importance in improving the employment opportunity and animal protein production in Nigeria. The production of eggs has been the factor of the greatest economic importance in poultry production thus the marketing of this product cannot be overemphasized (Nse-Nelson et al., 2017). Branckaert and Guèye (2000) observed that poultry products in most developing countries, especially in Africa, are still expensive and that the marketing system is generally informal and poorly developed.

Agricultural marketing dictates how often the producer will increase and /or produce their output/yield. A good marketing organization directs production along the most suitable needs of the consumers. The market mechanisms have to be efficient to be able to play the role of propelling yield (Esiobu et al., 2014b). Marketing is concerned with all stages of operations which include the movement of commodities from the farms to the consumers. It involves the performance of all activities involved in the flow of goods and services from the point of initial production until they are in the hands of the ultimate consumers. Most of the eggs marketed and consumed in Nigeria come from poultry birds. Only little attention is given to other sources such as ducks, turkey, guinea fowl and geese because of their ability to lay few eggs (Rahman and Yakubu, 2005). As a result of the fragile nature of eggs, its marketing has been influenced by the difficulties in handling, transportation and distribution to the consuming unit. This has also influenced the cost of eggs in the market to a point that an average Nigerian cannot afford to buy eggs, and as a result failed to meet up with the standard nutrition requirement for protein intake per day or monthly. Due to the peculiar nature of egg, it becomes imperative to carry out a 
scientific survey of its marketing in the study area. The specific objectives of the study are to describe the socio-economic characteristics of the respondents, determine the structure of the egg markets, determine costs and return of egg marketing and examine the factors that influence the profitability of egg marketing.

Olukosi et al. (2007) defined marketing costs as the actual expense incurred in the performance of the marketing functions as commodity moves from the farm to the ultimate consumers. It includes the cost of transport, handling, marketing charges, and cost of assembling, processing, distributions, packaging, sales, promotion and advertisement cost and other costs such as taxes, levies and excise duties.

Ekunwe and Alufohai (2009) reported in their study that the marketing of egg in Benin City, Edo State, Nigeria was viable and highly recommended as a means of gainful employment; thus, this necessitated the need to ascertain if it was the same or not by carrying out a similar study to analyze the poultry egg marketing in Ijebu Ode Local Government Area of Ogun State, Nigeria. Therefore, the specific objectives were to examine the socio-economic characteristics of poultry egg marketers, determine the profitability of poultry egg marketing, examine the marketing efficiency of poultry eggs, examine the factors that influence the sales revenue of marketers, and examine the problems associated with poultry egg marketing.

\section{METHODOLOGY}

\section{The study area}

The study was carried out in Ijebu-Ode metropolis, Ogun State. Ijebu-Ode is located at Longitude 3.180 E and Latitude 6.470 N. It is one of the 20 Local Government Areas (LGA) that make up Ogun State and the second largest urban centre in Ogun State in terms of population and infrastructural facilities, being next only to Abeokuta the state capital. Since the last two decades, the town has proved to be a rapidly growing and expanding urban centre. Its importance as an administrative headquarters and commercial centre predates the colonial period. Ijebu-Ode is a medium sized city with a population of over 192,000 (Solaja et al., 2017).

\section{Data collection and Sampling techniques}

Data was collected using purposive and simple random sampling techniques. Two main markets known for poultry egg marketing in Ijebu-Ode LGA were purposively selected due to the concentration of high profile poultry egg marketers (i.e Oke-Ajemarket and New market). From each of the two markets, 45 questionnaires were administered to the poultry marketers using a simple random sampling technique, thus, given a sample size of 90 respondents. However, only 81 questionnaires were retrieved and used for the analysis.

\section{Data analysis techniques}

Descriptive statistics such as mean, frequency distribution tables and percentages were used to analyse the socio-economic characteristics of the marketers and the problems associated with the poultry egg marketing. Gross margin was used to analyse the profitability of the poultry egg 
Journal DOI: 10.46654/ij.24889849

Vol. 6, Issue 10 (October, 2020) | www.ijaar.org

Article DOI: 10.46654/ij.24889849.e61016

business. Ordinary Least Square (OLS) regression model was also used to analyse the factors that influence the sales revenue of the marketers in the study area.

Gross margin is expressed as:

$$
\text { Gross margin }=\text { Gross sales }- \text { Total variable cost }
$$

Marketing efficiency is expressed as:

$$
\text { Marketing efficiency }=\frac{\text { Total revenue }}{\text { Total variable cost }} \times 100
$$

Linear production function is implicitly expressed as:

$$
Y=f\left(X_{1}, X_{2}, X_{3}, X_{4}, U\right)
$$

Where;

$Y=$ Sales revenue

$X_{1}=$ Cost of labour ( $¥ /$ man days)

$X_{2}=$ Marketing experience (years)

$X_{3}=$ Cost of purchase $(\mathrm{N})$

$X_{4}=$ Transportation cost $(\mathrm{N})$

$U=$ Error term 


\section{RESULTS AND DISCUSSION}

Table 1 shows the distribution of the respondents. Females (66.7\%) are the majority of the respondents, while $33.3 \%$ are male. This implies that the marketing of poultry eggs in Ijebu-ode is dominated by females and is in agreement with the study of Ekunwe and Alufohai (2009) on the economics of poultry egg marketing in Benin City, Edo state, Nigeria, which opined that egg marketing was a feminine business. The result also revealed that the majority of the marketers are between the ages of 26-35 years, $18.5 \%$ of the marketers are between 36 and 45 years old. This implies that middle aged and active individuals are involved in the selling of poultry eggs in the study area.

Majority (54.3\%) of the marketers are married while $32.17 \%$ of them are single. The result also shows that most (75.3\%) of the sellers have household size of $1-5$ persons whereas, $24.7 \%$ have household size of 6-10 persons. Also, secondary school certificate holders constituted the majority $(60.5 \%)$ of the marketers followed by primary school certificate holders $(18.5 \%)$.

Furthermore, $49.4 \%$ of the sellers have marketing experience of $1-5$ years followed by those (43.3\%) with experience of between 6-10 years. Likewise, $49.4 \%$ of the sellers capital is sourced from personal accounts whereas, $43.2 \%$ of them acquired there capital through cooperative societies. 
International Journal of Advanced Academic Research (Sciences, Technology and Engineering) | ISSN: 2488-9849

Journal DOI: 10.46654/ij.24889849

Article DOI: 10.46654/ij.24889849.e61016

Table 1: Socio-economic characteristics of the respondents $(n=81)$

\begin{tabular}{|c|c|c|}
\hline Variable & Frequency & Percentages \\
\hline \multicolumn{3}{|l|}{ Sex } \\
\hline Male & 27 & 33.3 \\
\hline Female & 54 & 66.7 \\
\hline \multicolumn{3}{|l|}{ Age } \\
\hline $16-25$ & 3 & 3.7 \\
\hline $26-35$ & 49 & 60.5 \\
\hline $36-45$ & 15 & 18.5 \\
\hline $46-55$ & 14 & 17.3 \\
\hline \multicolumn{3}{|c|}{ Marital status } \\
\hline Single & 26 & 32.1 \\
\hline Married & 44 & 54.3 \\
\hline Divorced & 1 & 1.2 \\
\hline Widowed & 10 & 12.3 \\
\hline \multicolumn{3}{|c|}{ Household size } \\
\hline $1-5$ & 61 & 75.3 \\
\hline $6-10$ & 20 & 24.7 \\
\hline \multicolumn{3}{|l|}{ Religion } \\
\hline Muslim & 49 & 60.5 \\
\hline Christian & 32 & 39.5 \\
\hline \multicolumn{3}{|c|}{ Educational background } \\
\hline No formal & 14 & 17.3 \\
\hline Primary & 15 & 18.5 \\
\hline Secondary & 49 & 60.5 \\
\hline Tertiary & 3 & 3.7 \\
\hline \multicolumn{3}{|c|}{ Marketing experience } \\
\hline $1-5$ & 40 & 49.4 \\
\hline $6-10$ & 35 & 43.3 \\
\hline $11-15$ & 6 & 7.4 \\
\hline \multicolumn{3}{|c|}{ Membership of Association } \\
\hline Yes & 39 & 48.1 \\
\hline No & 42 & 51.9 \\
\hline \multicolumn{3}{|c|}{ Source of Capital } \\
\hline Personal & 40 & 49.4 \\
\hline Cooperative & 35 & 43.2 \\
\hline Friends & 5 & 6.2 \\
\hline Others & 1 & 1.2 \\
\hline TOTAL & 81 & 100 \\
\hline
\end{tabular}

Source: Field survey, (2016) 
The result of the cost and returns of poultry eggs presented in Table 2 below revealed that the cost of purchase per day of the sellers in Ijebu-ode was $\$ 822,697.00$ which accounted for $76.2 \%$ of the total cost while labour cost and transportation cost were $\$ 92,550$ and $\$ 95,900$ which accounted for $8.89 \%$ and $8.57 \%$ respectively. The total variable cost was $\$ 1,078,707.00$ whereas; the total revenue and gross margin were $\$ 1,227,449.65$ and $\$ 148,742.65$ respectively. This implies that the marketing of poultry eggs in the study area is profitable. The finding is in agreement with the study of Ekunwe and Alufohai (2009), on "Economic of Poultry Egg Marketing in Benin City, Edo State, Nigeria" that poultry egg marketing is a profitable business.

Table 2: Cost and Returns of poultry eggs

\begin{tabular}{lll}
\hline Items & Amount (\$) & Percentage of TVC \\
\hline Variable cost & & \\
Cost of purchase & $822,697.00$ & 76.2 \\
Transportation cost & 92,550 & 8.57 \\
Labour cost & 95,900 & 8.89 \\
Total variable cost & $\mathbf{1 , 0 7 8 , 7 0 7 . 0 0}$ & \\
Total revenue & $\mathbf{1 , 2 2 7 , 4 4 9 . 6 5}$ & \\
Gross margin & $\mathbf{1 4 8 , 7 4 2 . 6 5}$ & \\
\hline
\end{tabular}

Source: Field survey, (2016)

Table 3 shows the marketing efficiency of poultry eggs. The higher the efficiency ratio, the higher is the marketing efficiency. The efficiency of New market is higher than the efficiency of Oke-Aje market with the ratio of 1.30 while Oke-Aje market has ratio of 1.03 respectively. This means that New market is more efficient than Oke-Aje market.

Table 3: Marketing efficiency of poultry eggs

\begin{tabular}{lll}
\hline Items & Oke-Aje Markets & New Market \\
\hline Total revenue ( $)$ & $650,000.25$ & $577,449.40$ \\
Total variable cost $(Æ)$ & $633,682.00$ & $445,025.00$ \\
Profit $($ ) & $16,318.00$ & $132,424.00$ \\
Marketing efficiency & $\mathbf{1 . 0 3}$ & $\mathbf{1 . 3 0}$ \\
\hline
\end{tabular}

Source: Field survey, (2016) 
The Table 4 below shows the regression estimates of poultry egg sellers and the factors that determine the price of the sellers in the study area. The $R^{2}$ value of 0.548 indicates that the variables in the model explain $54.8 \%$ of variability in the amount of sales. The $\mathrm{F}$ value of 22.69 was highly significant at $1 \%$ level indicating a well fitted model. The data revealed that the negativity of labour cost and transportation cost leads to decrease in the revenue of poultry egg sellers in the study area. Storage cost and marketing experience are not significant at $(p>0.01)$. On the other hand, cost of purchase and transportation cost are significant at $(\mathrm{p}<0.01)$. That is, cost of purchase and transportation cost had a great influence on the price at which the eggs were sold by the sellers. Transportation cost and labour cost are negatively related to the sales revenue of the marketers, this implies that a decrease in transportation cost and labour cost will bring about an increase in the net return of the marketers. This result concurs with Nse-Nelson et al., (2017) who reported that a decrease in transportation cost and storage cost will bring about an increase in the net return accruing to egg marketers and vice versa.

Table 4: Regression estimates of poultry egg sellers

\begin{tabular}{lllll}
\hline Variables & $\begin{array}{l}\text { Regression } \\
\text { coefficient }\end{array}$ & Standard error & t value & P value \\
\hline (Constant) & 99.419 & 5.391 & 0.000 & \\
Labour cost & -0.140 & 11.574 & -1.517 & 0.133 \\
Marketing & 0.014 & 13.309 & 0.167 & 0.868 \\
experience & & & & $0.000^{* * *}$ \\
Cost of purchase & 0.565 & 0.093 & 6.102 & $0.000^{* * *}$ \\
Transportation cost & -0.289 & 14.474 & -3.602 & \\
R square & $\mathbf{0 . 5 4 8}$ & & & \\
F value & $\mathbf{2 2 . 6 9 2}$ & & & \\
Adjusted $\boldsymbol{R}^{\mathbf{2}}$ & $\mathbf{0 . 5 2 3}$ & & & \\
\hline Source: Field survey, $(2016)$ & $* * *$ Significant at $\mathrm{P}<0.01$ &
\end{tabular}

Table 5 shows the problems associated with poultry egg marketing. According to the marketers, poor pricing was the major problem affecting them, followed by poor transportation, losses due to breakages and inadequate storage facilities. About $8.6 \%$ of the sellers have problem of inadequate storage facilities, $43.2 \%$ have problem of poor pricing, and $30.9 \%$ of them have problem of poor transportation, $12.3 \%$ have problem of losses due to breakages while $4.9 \%$ of the sellers have all of the problems. This also agrees with the study of Okpeke and Ellah (2017) on "Analysis of Poultry Eggs Marketing in South-South Part of Nigeria: A Case Study of Ika South Local Government Area, Delta State, Nigeria". The result showed that inadequate capital, poor transportation, price fluctuations and exorbitant prices of poultry eggs were the major constraints faced by poultry egg marketers. 
Journal DOI: 10.46654/ij.24889849

Vol. 6, Issue 10 (October, 2020) | www.ijaar.org

Article DOI: 10.46654/ij.24889849.e61016

Table 5: Problems associated with poultry egg marketing

\begin{tabular}{lll}
\hline Items & Frequency & Percent \\
\hline Inadequate storage facility & 7 & 8.6 \\
Poor pricing & 35 & 43.2 \\
Poor transportation & 25 & 30.9 \\
Loss due to breakages & 10 & 12.3 \\
All of the above & 4 & 4.9 \\
TOTAL & $\mathbf{8 1}$ & $\mathbf{1 0 0 . 0}$ \\
\hline
\end{tabular}

Source: Field survey, (2016)

\section{CONCLUSION}

In conclusion, the results of the study revealed that females were the majority of the respondents with most of them in their active age and were fairly educated and were married. Poultry egg marketing was a profitable business in Ijebu-Ode. Marketing in "New market" was more efficient than in "Oke-Aje market". The cost of purchase and transportation cost were significant factors that contribute to the sales revenue $(\mathrm{p}<0.01)$ of egg marketers. It also showed that poor pricing, poor transportation facilities, loss due to breakages and inadequate storage facilities were the problems associated with poultry egg marketing in Ijebu-Ode.

\section{RECOMMENDATIONS}

Based on the findings of the study, the following recommendations were made:

1. There should be introduction of an effective pricing mechanism by Poultry Association of Nigeria that would be more favourable for poultry egg marketers.

2. There should be adequate provision of storage facilities for the marketers to preserve the eggs and they should be given proper training on handling to reduce breakages through the nexus of the Poultry Association of Nigeria and the marketers.

3. Advocacy for provision of good and accessible roads to government should be intensified to minimise the problem of poor transportation and loss of eggs in transit.

4. Marketers should be encouraged to form cooperatives so as to take advantage of economies of scale 


\section{REFERENCES}

Abanikannda, O.T..F, Olutogun O., Leigh, A.O. and Ajayi, L.A. (2007). Statistical Modelling of Egg Weight and Egg Dimensions in Commercial Layers. Inter. J. Poultry Sci. 6: 59-63.

Aihonsu, J.O.Y. and Sunmola, M.A. (1999). Optimallaying period for profitable and sustainable eggproduction.Ife Journal of Agriculture, 20: 67-80.

Alabi, R.A. and Isah, A.O. (2002). Poultry productionconstraints: The case of Esan West L.G.A of EdoState Nigeria. African Journal of LivestockExtension, 1: 58-61.

Branckaert, R.D.S. and Guèye,E.F. (2000). Poultry as a Tool in Poverty Eradication and Promotion of Gender Equality. FAO Programme for Support to Family Poultry Production.

Ekunwe, P.A. and Alufohai, G.O. (2009). Economic of Poultry Egg Marketing in Benin City, Edo State, Nigeria. Inter. J. Poultry Sci. 8: 166-169.

Esiobu N.S., Onubuogu G.C.and Okoli, B.N. (2014). Determinants of income from poultryegg production in Imo State, Nigeria: Aneconometric approach. Global Advanced Research Journal of Agricultural Science, 3 (7):186-199.

FAO (2012). Food and Agricultural Organization statistic online issue. www.fao.org

Nse-Nelson F.A., Kurumeh J.C. and Osondu K.R. (2017). Evaluation of poultry egg marketing in Ikwuano Local Government Area of Abia State, Nigeria. Agro-Science, 17 (1):1-6. DOI: $\underline{\text { https://dx.doi.org/10.4314/as.v17i1.1 }}$

Oji, U.O., and Chukwuma, A.A. (2007). Technical Efficiency of Small Scale Poultry-Egg Production in Nigeria: Empirical Study of Poultry Farmers in Imo State, Nigeria. Research Journal of Poultry Sciences, 1: 16-22.

Okpeke, M.Y. and Ellah, G.O. (2017). Analysis of Poultry Eggs Marketing in South-South Part of Nigeria. A Case Study of Ika South Local Government Area, Delta State, Nigeria. Global Journal of Agricultural Research. 6 (3):1-15, June 2017.

Oludele, M., Solaja, A.O., Omodehin, B., and Badejo, A. (2017).Socio-ecologies of solid waste in Ijebu-Ode, Ogun State, Nigeria. Recycling and Sustainable Development 10:1-8. Available at www.rsd.tfbor.bg.ac.rs.

Olukosi, J.O., Isitor, S.U. and Ode, M.O. (2007). Introduction to Agricultural Marketing and Prices. 3rd Edition. Principles and Application. Zaria, Kaduna.

Rahman, S.A. and Yakubu, A. (2005). Analysis ofpoultry egg production, distribution and consumption in parts of Nasarawa State, Nigeria. International Journal of Natural AppliedScience.1 (1):1- 4. 